\title{
How can one kill someone twice in Indonesian? Causal pluralism at the syntax-semantics interface
}

\author{
Yosuke Sato*
}

\begin{abstract}
This paper investigates the non-culminating, zero change-of-state construal of causative accomplishment verbs as well as its origin in Indonesian in order to shed light on the event/conceptual structure of this verb class. The paper first presents novel data illustrating that this construal is possible with an agentive subject, but not with a causer subject, thereby lending support to the Agent Control Hypothesis (Demirdache and Martin 2015), which is known to regulate the relationship between agentivity and non-culmination. The paper then addresses the question why Indonesian exhibits this agentive-sensitive distribution of the non-culminating interpretation. This fact is argued to follow from a close interaction of Martin's (2019) event-tokenization theory of two types of causation with the maximality requirement of the weak perfective operator (Altshuler 2014) independently developed for languages such as Thai, Hindi and Chinese. The proposed analysis receives support from time-frame adverbials and different interpretations imposed on VP complementation under aspectual predicates.
\end{abstract}

Keywords. non-culminating accomplishment verbs; event-tokenization; causal pluralism; time-frame adverbials; agent control hypothesis; agentivity

1. Introduction. Over the last five years or so, there has emerged an important crosslinguistically salient generalization regarding a particular interpretation of causative accomplishment verbs, captured under the name of the Agent Control Hypothesis (ACH) (Demirdache and Martin 2015; Martin 2015, 2019). This hypothesis regulates the availability of nonculminating, zero change-of-state $(\mathrm{CoS})$ construals associated with this Aktionsart class depending on the agentivity of their external argument referent. The purpose of this paper is to investigate the conceptual/event structure of causative accomplishment verbs in Indonesian, a language which has heretofore never been studied with focus on this particular topic.

The present article is structured as follows. In section 2, I introduce core data illustrating the non-culminating, zero $\mathrm{CoS}$ interpretation with causative accomplishment verbs in Indonesian such as bunuh 'to kill' and tutup 'to close'. The data will be used to confirm the typological robustness of the ACH from the perspective of Indonesian. In section 3, I address the question why this interpretation is possible with agentive causation, but not with non-agentive causation, and develop an account of this agentivity-sensitive split pattern. The account utilizes Martin's (2019) event-tokenization theory of causation types, according to which agentive causation is tokenized by two sub-event tokens - the agent's action and the theme's $\mathrm{CoS}$ - while non-agentive causation is tokenized only by one subevent token - the theme's CoS. In section 4, I provide three independent arguments for my proposed analysis based on different timings of the possible onsets of a causing event in the two types of cau-

\footnotetext{
*I thank Duk Ho-An, Mike Barrie, Tanmoy Bhattacharya, Lauren Clemens, Mitcho Yoshitaka Erlewine, Nobu Goto, Beth Levin, Seunghun Lee, Keiko Murasugi, Mamoru Saito, Makiko Tawa, Shiao Wei Tham, Satoshi Tomioka, Yusuke Yagi, Jianrong Yu, Elisabeth Verhoeven, and Philip Wolff for helpful discussions and questions. Thanks also go to the participants of the (non-)agentivity workshop at the National University of Singapore (May 2019), the interface workshop at the International Christian University (May 2019), the 27th Japanese/Korean Linguistics Conference at Sogang University (October 2019) and the $94^{\text {th }}$ annual meeting of the Linguistic Society of America for comments. Special thanks to Heidi Harley and Fabienne Martin for valuable discussions on the topic presented here and to Dwi Hesti Yuliani for all the Indonesian data included here. This research is supported by the Japan Society for the Promotion of Science Grant-in-Aid for Scientific Research (C) (\#JP19K0056). Author: Yosuke Sato, Seisen University (yosukes1129@ seisen-u.ac.jp).
} 
sation as measured by aspectually conflicting time-frame adverbials and the distinct entailments of causative complementation under aspectual predicates such as mulai 'to begin' with regard to the attainment of the theme's $\mathrm{CoS}$, and the distinction between imminent and remote culmination interpretations of the two causation types under progressive contexts. Section 5 is the conclusion.

2. The non-culminating, zero CoS accomplishment verbs in Indonesian. It is well-known since Tai (1984) that in Mandarin Chinese, causative accomplishment verbs such as sha 'to kill' do not necessarily entail the resulting $\mathrm{CoS}$ of the theme argument lexically denoted by the verbs, as shown by the acceptability of (1). To insist on the attainment of the intended result state, the V-V compound sha-si 'kill-die' must be instead.
Zhangsan
\{sha-le/\#sha-si-le\}
Lisi
liangci,Lisi
dou mei
si.
Zhangsan
kill-PFV/kill-die-PFV Lisi twice Lisi
'Zhangsan killed Lisi twice, but Lisi didn't die.'
QUANT NEG die
(Tai 1984:291)

Causative accomplishment verbs in Indonesian such as bunuh 'to kill' and tutup 'to close' exhibit the same behavior as those in Mandarin Chinese in that they permit this non-culminating, zero $\mathrm{CoS}$ construal, as shown by the felicity of the examples in $(2 \mathrm{a}, \mathrm{b})$.

a. Budi membunuh Ali, tapi dia tidak mati.
Budi kill Ali but he
'Budi killed Ali, but he didn't die.'
Esti mentutup pintu, tapi tidak tertutup.
Esti close door but NEG close
'Esti closed the door, but it didn't close.'

(Agent)

(Agent)

Importantly, however, the same verbs strictly prohibit the relevant construal when the volitional agent argument in subject position is replaced with a non-volitional causer subject, as witnessed by the semantic anomaly of the examples in $(3 a, b)$, which minimally differ from the examples in $(2 \mathrm{a}, \mathrm{b})$ in terms of the subject thematic role (agent vs. causer).
a.
Gempa bumi
Ali, \#tapi dia
tidak mati.
(Causer) quake earth kill
Ali but he NEG die
'The earthquake killed Ali, but he didn't die.'
b. Angin mentutup pintu, \#tapi tidak tertutup. wind close door but NEG close
'The wind closed the door, but it didn't close.'
(Causer)

The contrast in acceptability between (2) and (3) supports the $\mathrm{ACH}$, which is defined in (4).

(4) Agent Control Hypothesis (ACH) (Demirdache and Martin 2015:187)

The availability of non-culminating construals for accomplishments correlates with the control of the agent over the described event: whenever an accomplishment ... admits a nonculminating construal, this is the case only if we can ascribe agenthood to the subject. If the subject of the very same verb is a (pure) causer, culmination cannot be canceled.

The ACH was originally proposed by Demirdache and Martin (2015): see also Martin (2015, 2019) and Martin and Schäfer (2015) for further developments and consequences of the ACH. The hypothesis has already been shown to receive ample confirmation from a wide range of ge- 
netically unrelated (families of) languages. Data from some representative examples of languages are given below to support the cross-linguistic robustness of the $\mathrm{ACH}{ }^{1}$

(5) English (Martin and Schäfer 2015:87)

a. Ivan taught me Russian, but I did not learn anything. (Agent)

b. Lipson's textbook taught me Russian, \#but I didn’t learn anything. (Causer)

(6) French (Martin 2015:248)

a. Dr Li m’a soigné, mais je n'ai pas guéri du tout. (Agent)

Dr Li me=has treated but I NEG=has NEG cured at all

'Dr. Li treated me, but I didn't recover at all.'

b. Ce séjour chez ma soeur m'a soigné, \#mais je n'ai pas

this stay at my sister me=has treated but I NEG=has NEG

guéri du tout. (Causer)

cured at all

'This stay at my sister's treated me, but I didn't recover at al.'

(7) Salish (Halkomelem/Saanich) (Jacobs 2011; Kiyota 2008)
a. ni? cən qa:y-t t ${ }^{\theta} \partial$ spə? $ə \theta$ ?i? ?əwə ni? -əs
AUX 1.SBJ die-CTR DET bear and NEG AUX-3SG.SBJ die
'I killed the bear, but it didn't die.'

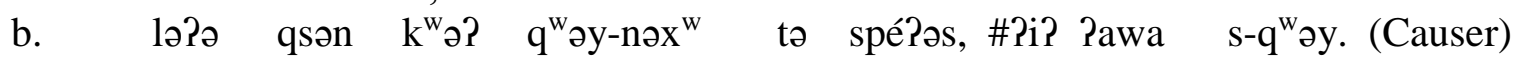
AUX 1.SBJ INF die-NCTR.TR DET bear ACC NEG NOM-die
'I (accidentally) killed the bear, but it didn't die.'

(8) Japanese (cf. Tsujimura 2003)
a. Megumi-ga doa-o
Megumi-NOM door-ACC close-PST-but close-NEG-PST-COP-SFP-SFP
'Megumi closed the door, but the door didn't get closed.' sudden wind-NOM door-ACC close-PST-but close-NEG-PAT-COP-SFP-SFP
'A sudden window closed the door, but the door didn't get closed.'
b. Kyuuna kaze-ga doa-o sime-ta-kedo, \#simara-naka-tta-nda-yo-ne. (Causer)

Tsujimura (2003) is the first to explicitly point out the correlation between the availability of the nonculminating interpretation of causative accomplishment verbs and the agentivity of their subject argument on the basis of her observation regarding 'event cancelation phenomena' in Japanese; see also Ikegami (1980/1981, 1981, 1985) and Kageyama $(1996,2002)$ for relevant discussions and important observations hinting at this correlation in Japanese. Tsujimura (2003:398) writes thus:

(9) “...what seems to be common in all languages that exhibit the event cancellation phenomenon is intentionality. ... In Japanese, if the agent of the action denoted by the verb does not have the intention to carry out the event but the event instead takes place by accident, cancellation of the event is not possible ... Thus a remaining challenge is determining whether and how such intentionality should be represented in the lexical representation of verbs."

\footnotetext{
${ }^{1}$ Lee's (2015) 'Subject Intention Generalization', as defined in (i), seems to also capture the essential insight behind the ACH that subject agentivity has profound repercussions on the (non-)culmination of the VP event.

(i) Subject Intention Generalization (Lee 2015:107):

Non-occurrence of an event requires the subject's intention regarding the event.
} 
We have seen thus far that the non-culminating, zero CoS interpretation of causative accomplishment verbs in Indonesian is sensitive to the agentivity of the subject argument, thereby adding further credence to the typological validity of the ACH from Indonesian. How is it, then, that agentivity has this particular repercussion on non-culminativity of this Aktionsart class at the level of event structure/conceptual structure? How is this agentivity best represented at the event-conceptual system? How does our treatment of agentivity at this system (how it may turn out to be) interact with the syntactic representation for causative accomplishment verbs? The rest of this paper attempts to develop a specific proposal to answer these questions, which heavily draws on Martin's (2019) recent event-tokenization theory of causation types as well as its central analytic tools and diagnostics developed therein.

3. Causal pluralism, event-tokenization and the weak partitive operator. Causal Pluralism upholds the position that causation is not a monolithic kind of cause-effect relations among things in the external world. I propose that natural language reflects this mode of human cognition by drawing a fundamental division between agentive causation and non-agentive causation. More specifically, following Martin's (2019) event-tokenization theory, I propose that agentive causation is tokenized at the language-cognition interface by two sub-event tokens - the agent's action and the theme's $\mathrm{CoS}$ whereas non-agentive causation is tokenized by only one sub-event token - the theme's CoS.

In section 3.1, I will first give a brief outline of Martin's (2019) theory to lay the groundwork for my analysis of the agentivity-sensitive availability of non-culminating, zero CoS construals of causative accomplishment verbs in Indonesian, to be articulated in section 3.2. In section 3.3, I will present two independent arguments based on Tagalog and English in favor of the assumption that the language-based cognition of agentive causative accomplishment verbs involves the division of one causative macro-event into an ordered pair of the agent's causally inert preparatory action(s) and the theme's CoS component.

3.1. MARTIN'S $(2015,2019)$ EVENT-TOKENIZATION THEORY AND CAUSAL PLURALISM. Let us introduce Martin's (2019) theory of the ACH, as developed for causative accomplishment verbs in Asian languages such as Thai, Hindi, and Mandarin Chinese, in order to set the analytical framework from which to understand the Indonesian facts noted in section 2. Martin's theory is based on two fundamental assumptions depicted in Figure 1 (Martin 2019:20).

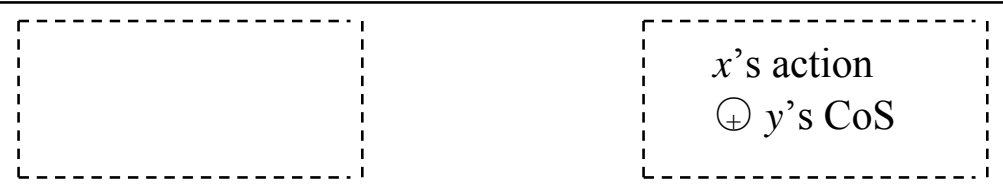

no eventuality denoted by the subject DP causing event denoted by the VP

(a) Causal chain denoted by an agentive lexical causative statement

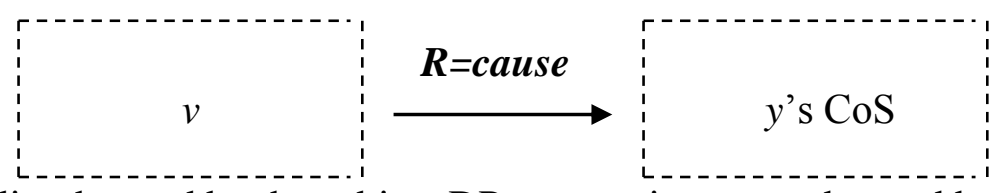

eventuality denoted by the subject DP causing event denoted by the VP

(b) Causal chain denoted by a non-agentive lexical causative statement (with $\mathrm{R}=$ cause)

Figure 1. Causal chains denoted by lexical causative statements 
One assumption, adopted in Martin's (2019) event-tokenization theory, is with regard to how the agent vs. causer argument is introduced in the syntactic derivation through different flavors of $v$ heads (Schäfer 2008; Harley 2013). Martin suggests that the agent argument is introduced by the functional head Voice $_{a g}$. This functional head relates the external argument $x$ it introduces in its specifier to the event $e$ introduced by the VP it combines with and denotes that $x$ is the agent of $e$ without introducing any further event. The causer argument, by contrast, is introduced by Voice ${ }_{c}$, which introduces a further eventuality $v$ argument saturated by the DP subject (construed either as an event or a state argument) as well as a relation $R$ between $v$ and the event $e$ denoted by the causative VP. The relation $R$ between the eventuality denoted by the eventuality $v$ argument and the causing event denoted by the VP is prototypically understood as a causal relation.

The assumption mentioned above correctly predicts the contrast in grammaticality between (10a) and (10b).

(10) a. Fred ${ }_{\mathrm{i}}$ accidentally shot his dog on December 23 ! $* \mathrm{He}_{\mathrm{i}}$ eventually killed it on December 25.

b. Fred accidentally shot his dog on December 23! This gunshot eventually killed it on December 25.

(Martin 2019:16)

The impossibility of separate modification by two temporal expressions in (10a) - on December 23 and on December 25 - directly follows from the semantic function of Voice ag $_{a g}$ to relate the agent argument to the VP-event without introducing any extra eventuality argument, given the natural assumption that a temporal adverb must take scope over a single event (Martin 2018). By contrast, such a modification structure is available in (10b). This is also expected under the event-structural

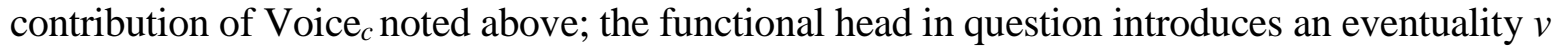
argument saturated by the event- or state-denoting subject DP and links it to the causing event $e$ denoted by the causative VP through the relation of causation. It follows, then, that $v$ and $e$ can be separately accessed by the two temporal expressions, as witnessed in (10b).

The other assumption, adopted by Martin (2019), concerns the number of sub-event tokens involved in the tokenization of the causing event denoted by agentive vs. non-agentive causation types. Concretely, the agentive causation type is tokenized by two sub-parts, namely, an action performed by the agentive subject referent and an ensuing CoS on the part of the theme's referent. These two sub-event tokens are then analyzed as constituting one single macro causing event for the denotation of the causative VP. By contrast, the non-agentive causation type is tokenized by the $\mathrm{CoS}$ of the theme referent only. This means that the non-agentive causation type has the same interpretation as its anti-causative/inchoative variant since in both cases the relevant events are fleshed out by the $\mathrm{CoS}$ on the part of the theme argument, barring the presence vs. absence of the external argument that introduces an eventuality $v$ argument in the case of the causative counterpart.

\subsection{ANALYSIS OF THE ACH EFFECTS IN INDONESIAN CAUSATIVE ACCOMPLISHMENT VERBS.} Having reviewed the basic assumptions of Martin's (2019) event-tokenization approach to causation types as our analytical framework, let us now come back to our original question we started this paper with: why is the non-culminating, zero CoS reading possible in Indonesian causative accomplishment verbs with agent subjects, but not with causer subjects?

The perfective operator PFV is standardly defined as denoting that the event $e$ it is existentially quantified over is complete with respect to a particular predicate $\mathrm{P}$. This standard definition of the perfective is given in (11).

$$
\left[\left|\mathrm{PFV}_{C}\right|\right]=\lambda P \exists e(P(e)) \text { (standard perfective) }
$$

(Martin 2019:8)

However, various researchers, including Koenig and Muansuwan (2000), Altshuler (2014, 2016), 
Martin (2019, forthcoming), Martin and Gyarmathy (forthcoming), and Martin et al. (2018), propose that South Asian and (South) East Asian languages such as Thai, Hindi, and Mandarin Chinese have a perfective operator whose denotation is fundamentally different from this standard definition. More concretely, they suggest that the perfective operator in these languages forms a "partitive operator" (Altshuler 2014) in the sense that they denote not event completion, but event maximality to account for the availability of non-culminating interpretations of accomplishment verbs in these languages. This partitive version of the PFV - which Martin (2019) and Martin and Gyarmathy dub a weak perfective - can be defined as in (12). A simple version of the intricate modal-based definition of the partitive operator originally proposed by Altshuler (2014) is reproduced in (13) from Martin (2019).

$\left[\left|\mathrm{PFV}_{M}\right|\right]=\lambda P \exists e(\operatorname{MAX}(e, \mathrm{P}))($ weak perfective)

(Martin 2019:9)
$\operatorname{MAX}(e, P):=$
a. $\quad e$ is a part of a possible $\mathrm{P}$-event and
b. $\quad e$ is not a proper part of any actual event that is part of a possible P-event.

(Martin 2019:9)

(12) refers to what Altshuler (2014:761) calls the Maximal Stage Requirement, a requirement he originally developed for the simple form of the perfective in Hindi. Altschuler essentially points out that this requirement can be satisfied either when an event culminates or ceases to develop toward a VP-denoted event. Martin (2019) shows that in Mandarin Chinese, the proposed definition of the $\mathrm{PFV}_{M}$, morphologically realized as -le, correctly accounts for the semantic incongruity of (14a) as well as the acceptability of (14b).
a. \# Lùlu kāi-le
Lulu open-PFV
nèi-shàn
mén,
érqiě
hái door and still
'Intended: Lulu opened that door, and she is still opening it.'
b. Lùlu kāi-le nèi-shàn mén, dànshì mén gēnběnméi kāi.
Lulu open-PFV that-CLF door but door at.all NEG.PFV open
'Lulu opened that door, and it didn't open at all.'

(Martin 2019:9)

As stated above, the partitive operator in question requires that the door-opening event described in the first clause is maximal; that is, the relevant event must be a complete P-event or cease to develop towards a P-event in the real world. The example in (14a) is semantically anomalous because the second clause indicates that the event in question is still ongoing, in violation of the maximality requirement imposed by the $\mathrm{PFV}_{M}$. This example is to be contrasted with the acceptable example in (14b), where the relevant requirement is not overtly violated by anything.

We are now ready to complete Martin's (2019) explanation for the ACH effects through the interaction of her event-tokenization theory with the denotation of the weak/partitive operator. Recall that the agentive causation type is tokenized by the agent's action and the theme's CoS. Given the semantics of the $\mathrm{PFV}_{M}$ provided in (13), the event $e$ it is existentially quantified over is either a complete $\mathrm{P}$ event or ceases to progress toward the P-event. In other words, the maximality requirement imposed by the $\mathrm{PFV}_{\mathrm{M}}$ is satisfied as long as there is a proper subpart of a complete P-event in the actual word that the operator can quantify. Consequently, in the case of the agentive causation type, $\mathrm{PFV}_{M}$ may be existentially quantified over any proper part of (a series of) agent's action conducted by the subject referent, thereby yielding no contradiction with subsequent denials of the $\mathrm{CoS}$ of the theme argument. This option is not available in the case of the non-agentive caution type, however. This type is tokenized, by hypothesis, by the theme's CoS sub-event token alone. Therefore, $\mathrm{PFV}_{M}$ must be quantified over this 
sub-event token and return at minimum (a part of) the theme's CoS. This requirement, then, clashes with subsequent denials of the CoS of the theme argument.

Martin's analysis outlined above can be extended straightforwardly to the Indonesian examples in (2-3), which we have shown in section 2 to exhibit the ACH effect. For a start, the infelicity of the examples in $(15 \mathrm{a}, \mathrm{b})$ indicates that Indonesian is endowed with the partitive perfective operator $\mathrm{PFV}_{M}$ as in Mandarin Chinese, though the operator is phonetically silent.
a.
Budi membunuh
Ali,
\#dan
masih sed
Budi kill
Ali and still PROG kill-him
'Budi killed Ali, and he is still killing him.'
b. Esti mentutup pintu, \# and masih sedang mentutup-nya.
Esti close door but still PROG close-it
'Esti closed the door, and she is still closing it.'

The $\mathrm{PFV}_{M}$ in the first clause in these examples imposes the maximality requirement to the effect that the killing event or the door-opening event has to be complete or has to cease to progress any further toward a P-event at the utterance time. However, this requirement is violated by the second clause, which indicates that the event is still in progress at the utterance time.

The contrast between $(2 \mathrm{a}, \mathrm{b})$, with an agentive subject, and (3a, b), with a non-agentive subject, now receives the same explanation as in Mandarin Chinese. The relevant examples are repeated here as $(16 \mathrm{a}, \mathrm{b})$ and $(17 \mathrm{a}, \mathrm{b})$, respectively.
a.
Budi membunuh
Ali, tap
dia tidak mati. (Agent)
Budi kill Ali but he NEG die 'Budi killed Ali, but he didn't die.'
b. Esti mentutup pintu, tapi tidak tertutup. (Agent)
Esti close door but NEG close
'Esti closed the door, but it didn't close.'
a. Gempabumi membunuh
Ali, \#tapi dia
tidak mati. (Causer)
quake earth kill
Ali but he
'The earthquake killed Ali, but he didn't die.'
b. Angin mentutup pintu, \#tapi tidak tertutup.
wind close door but NEG close
'The wind closed the door, but it didn't close.'
(Causer)

The causative VPs in $(16 \mathrm{a}, \mathrm{b})$, instantiating the agentive causation type, are tokenized by the agent's action and the theme's CoS sub-event tokens. $\mathrm{PFV}_{M}$, then, may be existentially quantified over any sub-part of the agent's action that does not yet cause any CoS on the part of the theme referent, yielding the non-culminating construal of the causative verbs with agentive subjects. The causative VPs in $(17 \mathrm{a}, \mathrm{b})$, on the other hand, instantiate the non-agentive causation type, meaning that they are tokenized by the theme's CoS sub-event token alone. Hence, $\mathrm{PFV}_{M}$ requires that at least some sub-part of this change must be realized in the actual world to satisfy the maximality requirement. This requirement, then, is contradicted by the denial of any CoS denoted by the second clause, giving rise to contradiction in $(17 \mathrm{a}, \mathrm{b})$.

Recall that under Martin's theory, the non-agentive causation cases as in (16a, b) are interpreted exactly the same way as their anti-causative/inchoative counterparts in that their interpretations are both achieved through the single sub-event token - the theme's CoS component. Accordingly, we can also correctly predict that anti-causative/inchoative examples as in (18a, b) result in contradiction. 


al mati, \#tapi dia tidak mati.
Ali die but he NEG die
'Ali died, but he didn't die.'
b. Pintu tertutup, \#tapi tidak tertutup.
door close but NEG close
'The door closed, but it didn't close.'

To summarize, I have shown in this subsection how Martin's (2019) event-tokenization theory of two causation types interacts with the partitive perfective operator $\mathrm{PFV}_{M}$ in Indonesian to yields the agent-sensitive distribution of the non-culminating, zero $\mathrm{CoS}$ reading of causative accomplishment verbs in the language as predicted by the $\mathrm{ACH}$.

\subsection{Two Arguments For Sub-Event ToKens in AgEntive AcComplishment Verbs. There} are two crucial assumptions within my analysis for the non-culminating, zero $\mathrm{CoS}$ interpretation of causative accomplishment verbs in Indonesian couched within Martin's (2019) eventtokenization theory. One is that the structured meanings of this class may contain two sub-event tokens which map to the agent's action and the theme's $\operatorname{CoS}$ for agentive causation. The other is that the agentive causation type has both of these two sub-event tokens, but the non-agentive causation type has only the latter token. In this section, I provide two independent pieces of evidence from Tagalog and English for the first assumption above, i.e., for the proposed identification of the two sub-event tokens in causative accomplishment verbs. The Indonesian data directly supporting the second assumption will be discussed in detail in section 4 .

Tagalog has a well-known morphological distinction between the neutral $(\mathrm{N})$ form and the ability/non-voluntary action (AIA) form. Dell (1983) points out that the choice between these two forms plays an integral part in indicating the occurrence of the agent's action and the theme's intended CoS lexically implicated by the verb root. Dell (1983:181) writes thus:

(19) "The lexical meaning of the root tulak ('to push'-AUTHOR) involves two distinct ideas. One has to do with the agent's engaging in a certain action or "Maneuver" (pushing the rock), and the other has to do with a certain "Result" that may (but need not) be brought about by that Maneuver (the displacement of the rock)."

Examples in $(19,20)$ illustrate Dell's observation.

$\begin{array}{lllll}\text { ITINULAK ni } & \text { Ben ang } & \text { bato. } \\ \text { N-PFV-push GEN } & \text { Ben } & \text { NOM } & \text { rock } \\ \text { 'Ben pushed the rock.' } & \text { (+Manuever, } \varnothing \text { Result) }\end{array}$

(Dell 1983:179)

(20) NAITULAK ni Ben ang bato. AIA-PFV-push GEN Ben NOM rock 'Ben pushed the rock.' (+Maneuver, + Result)

a. $\quad$ 'Ben managed to move the rock by pushing it.' (ability)

b. 'Ben accidentally moved the rock by pushing it.' (non-voluntary action)

(Dell 1983:180)

In (19), the sentence-initial verb is marked with the $\mathrm{N}$-form. Dell observes that here, Ben must have participated in the action of pushing the rock, but it does not have to be the case for the sentence to be true that the rock underwent any displacement as the result of his action(s): the rock may well be in exactly the same position as it was before the action(s) took place. In (20), on the other hand, the verb is marked with the AIA form. In this case, the rock that Ben pushed must 
have been displaced from its original position to some other position as the result of his pushing action(s), whether they were intentional or not. Equally telling is Dell's observation that negation in Tagalog specifically targets the meaning components that were highlighted by the choice of the N vs. AIA forms. Let us see what happens when the verbs in $(19,20)$ are negated. Examples in $(21,22)$ are cases in point:

$\begin{array}{llllll}\text { hindi } & \text { ITINULAK } & \text { ni } & \text { Ben } & \text { ang } & \text { bato. } \\ \text { NEG } & \text { N-PFV-push } & \text { GEN } & \text { Ben } & \text { NOM rock } & \text { rock } \\ \text { 'Ben did not the rock.' (-Maneuver, } \varnothing \text { Result) }\end{array}$

\begin{tabular}{|c|c|c|}
\hline 110 & $K$ & ni \\
\hline & AIA-PFV-push & GEN \\
\hline
\end{tabular}

'Ben did not push the rock.' (ØManeuver, -Result)

a. 'Ben managed to move the rock by pushing it.' (ability)

b. 'Ben accidentally moved the rock by pushing it.' (non-voluntary action)

(Dell 1983:181)

In (21), the negative marker hindi 'not' removes the erstwhile positive specification of the Maneuver or the agent's action which was manifest in (19). In (22), by contrast, the same marker now removes the positive specification of the Result or the theme's CoS component from its affirmative variant in (20). Of crucial important for our present purposes is that Dell's observation indicates that Tagalog has a fine-tuned morphological means to segregate the eventstructural meaning of accomplishment verbs into the agent's preparatory action(s) and the theme's CoS component, exactly as proposed by Martin $(2015,2019)$. I take the existence of this type of language to furnish independent support for the two-component analysis of the agentive causation type in other languages as well, including Indonesian.

Recent findings by Truswell (2011a, b) lend further support for the central idea adopted in this paper that the event-structural interpretation of accomplishment verbs involves the additional agent's action component only when it occurs with an agentive subject. Consider (23a, b):

(23) a. I am traveling to Utrecht.

b. I am arriving in Utrecht.

(Truswell 2011a:3)

Truswell (2011a) points out that (23a) is acceptable if the speaker's current action forms part of the plan which she/he is capable of realizing to reach Utrecht (e.g., boarding an airplane to Schipol, or taking a local train to Utrecht from the airport, etc.) - which Truswell calls a mentally delimited event. (23b), by contrast, is only acceptable if the speaker is arriving into Utrecht at any minute, and hence reports a physically delimited event. Truswell argues, based on the reported contrast in (23a, b) and several other examples of this kind, that when an accomplishment VP combines with an agentive external argument in subject position, then the event described by the VP can be bigger than when it does not contain such an argument because such a event may be construed as containing a series of the agent's action together with a description of the lexically encoded goal/culmination. A similar argument for the physically delimited vs. mentally delimited event depending on the agentivity of the subject can be constructed on the basis of the difference between the accomplishment VP climb a mountain and the achievement VP reach a summit. Truswell (2011b:99) writes thus:

"... what distinguishes climbing a mountain from reaching a summit in terms of the tools we have at our disposal? The most obvious distinction is that the preparatory process of climb a mountain consists of a series of agentive actions - before the actual clambering up- 
wards starts, there is the business of preparing equipment, planning routes, traveling to the foot of the mountain, and so on, carried out with the intention of climbing that mountain. Meanwhile, the preparatory process of reach the summit consists only of approaching a particular location, which is not an agentive action - a piece of wood would reach a summit as early as a human could, if it was blown there by a strong wind."

Accomplishment VPs with an agentive subject such as climb a mountain can be understood as forming a mentally extended, macro-event involving the agent's preparatory actions together with the telos of the plan whereas achievement VPs with a non-agentive subject such as reach a summit cannot be construed this way, limiting its interpretation to the physically delimited event. This contrast, therefore, can be taken to suggest a deep correlation between the subject's agentivity and the extra agent's action token introduced by an agentive accomplishment verb. ${ }^{2}$

4. Independent evidence for the causal pluralism hypothesis. Recall that the most crucial analytical assumption of my proposed extension of Martin's (2019) theory to the ACH effects in Indonesian was that the number of sub-event tokens was different depending on the agentivity of the subject argument. The agentive causation type is fleshed out by the agent's action and the theme's CoS whereas the non-agentive causation type is fleshed out by the theme's $\mathrm{CoS}$ as in anticausative/inchoative cases. We have shown how this difference interacted with the semantics of the weak/partitive operator to explain why the non-culminating interpretation of causative accomplishment verbs is available in Indonesian with agent subjects, but not with causer subjects. In section 3.3, we have seen two pieces of preliminary evidence from Tagalog and English to support the proposed identification of these two sub-event tokens making up one macro-event in the case of an agentive accomplishment. Now, is there any independent evidence, internal to Indonesian, in support for the central assumption above? In the rest of this section, I present three arguments for this assumption, all modeled on Martin's $(2015,2019)$ tests developed for accomplishment verbs in French/English.

Our first argument for this assumption is concerned with the different pattern of interaction of the two causation types with time-frame adverbials. Such adverbials are known to measure the time span between the onset and the result state of a complete eventuality denoted by a verb. Keeping this point in mind, let us now consider examples in (25) and (26), which instantiate the agentive and non-agentive causation types, respectively.

$\begin{array}{llllll}\text { (25) Pak Iwan } & \text { membunuh } & \text { ayam } & \text { dalam wakut sepulu menit, tapi } \\ \text { Mr Iwan } & \text { kill } & \text { chicken } & \text { in time ten minute but } \\ \text { sebenarnya } & \text { ayam-nya } & \text { mati hanya dalam waktu satu menit. } \\ \text { actually } & \text { chicken-the } & \text { die only in time one minute }\end{array}$

'Mr. Iwan killed the chicken in ten minutes, but actually the chicken died only in one minute.'

(26) Gempa bumi membunuh ayam dalam waktu sepulu menit, \#tapi

quake earth kill chicken in time ten minute but

sebenarnya ayam-nya mati hanya dalam waktu satu menit.

actually chicken-the die only in time one minute

'Mr. Iwan killed the chicken in ten minutes, but actually the chicken died only in one minute.'

The contrast between (25) and (26) is exactly what my analysis predicts. (25) can be truthfully uttered in the following scenario. At 8:00 am, on September 4, 2019, Iwan's sequence of prepara-

\footnotetext{
${ }^{2}$ See section 4 for a related discussion on Truswell's (2011a, b) observations on accomplishment verbs with agent vs. achievement verbs with causer subjects and their intriguing interpretive differences within progressive contexts.
} 
tory actions targeting the chicken started: for example, Iwan put his decision to kill the chicken into action for a breakfast, brought some necessary instruments such as knifes and what-not, stood up, and approached the chicken he was attempting to target on this particular morning. He finally put it to death at 8:10am. In other words, Iwan took a total of ten minutes to achieve the goal of killing the chicken. On the other hand, the chicken itself took one minute to die; for example, it was alive and intact at 8:09am but died a minute after at 8:10am as the result of Iwan's actions to kill it. The reason why the two apparently conflicting time-frame adverbials, dalam waktu sepulu menit 'in ten minutes' and hanya dalam waktu satu menit 'only in one minute', may occur with bunuh 'to kill' in (23) should be clear. (25), an instance of the agentive causation type, introduces the agent's action and the theme's CoS. Consequently, the time span of the latter sub-event token may well be shorter than the time span of the entire causing event that also contains the former sub-event token.

The anomaly of (26), on the other hand, shows that such a reading is inaccessible with the same VP, now with a causer subject. Again, this pattern receives a straightforward account. The nonagentive causation type is tokenized only by the theme's CoS token. Therefore, the example is necessarily interpreted such that the entire causing event (i.e., the $\mathrm{CoS}$ on the part of the chicken from the alive state to the dead state) would be completed in both ten minutes and only one minute, giving rise to logical contradiction. Also recall that the semantic interpretation of the non-agentive causation type is identical for all intents and purposes to that of its anti-causative/inchoative counterpart because both events may introduce only one sub-event token - the theme's CoS. Example (27) confirms that the latter construction yields semantic anomaly, just as (26) does.

Ayam mati dalam waktu sepulu menit, \#tapi sebenarnya $\begin{aligned} & \text { ayam-nya } \\ & \text { chicken die in time ten minute but actually }\end{aligned}$ chicken-the
mati hanya dalam waktu satu menit.
die only in time one minute

'Mr. Iwan killed the chicken in ten minutes, but actually the chicken died only in one minute.'

Our second argument in favor of the view that the agentive causation type has the agent's action token and the theme's CoS token, unlike the non-agentive causation type, which only has the latter token, comes from different interpretational requirements on the two causative VPs when embedded under aspectual predicates such as mulai 'to start'. More specifically, when a causative accomplishment VP is selected as the complement of such matrix predicates, this complementation structure requires the $\mathrm{CoS}$ of the theme argument to start with a causer subject at the utterance time, but not necessarily with an agent subject. Examples (28) and (29) illustrate this observation.

$\begin{array}{lll}\mathrm{Pak} \text { Iwan mulai membakar ikan. } & \text { fish } \\ \mathrm{Mr} & \text { Iwan start burn } & \text { fish } \\ \text { 'Mr. Iwan started burning the fish.' }\end{array}$

$\begin{array}{lll}\text { Api } & \text { mulai membakar } & \text { ikan. } \\ \text { fire } & \text { start burn } & \text { fish }\end{array}$

'The fire started burning the fish.'

For (28) to be truthfully uttered, some preparatory actions on the part of Iwan must have started. Crucially, however, no change on the part of the fish developing toward the intended result (i.e., the fish got burned) has to happen yet at the utterance time; thus, the fish may remain exactly in the same shape/color as before. This construal is possible in (28) precisely because this agentive causative example involves the agent's action and the theme's $\mathrm{CoS}$ as its sub-event tokens. The aspectual verb mulai 'to start' thus may modify the onset of the agent's action alone (i.e., a series of actions that the 
subject may take to get engage himself in the fish-burning event). (29), by contrast, entails that the fish in question has already started undergoing some change(s) at the utterance time ultimately leading to the intended result in a normal course of events; the fish, already turned to change its surface color to brown at least in part, for example. This entailment is necessarily manifested in (29) because this example, instantiating the non-agentive causation type, is tokenized only through the theme's CoS. Accordingly, the aspectual verb can only modify the onset of the theme's CoS which would lead to the expected outcome (i.e., the burned state of the fish).

Our third and final argument for the proposed analysis is based on the 'imminent' vs. 'remote' culmination readings brought about by non-agentive and agentive causative VPs, respectively, under progressive contexts (Bonomi 1997; Truswell 2011a, b; Martin 2015, 2019). Truswell (2011a, b), for one, points out that the example in (30) is false even in a situation where it is quite certain that the sea will destroy the sandcastle. On the other hand, the example in (31) is true even if the speaker is still preparing for a certain course of actions, such as gathering necessary instruments and approaching the sandcastle, before actually impacting on it to break the sandcastle.

(30) A: (Observing the sea advancing towards a fragile-looking sandcastle, but not yet touching it): What is the sea doing?

B: \# It is destroying that sandcastle.

(Truswell 2011a:12)

(31) A: (Observing B advancing towards a fragile-looking sandcastle and trying to stumble onto the sandcastle): What are you doing?

B: $\quad$ I am destroying that sandcastle.

The contrast between (30) and (31) indicates that under progressive contexts, the non-agentive causation forces the imminent culmination interpretation of the VP-event whereas the agentive causation allows for the remote culmination interpretation of the same event. This contrast, in turn, directly falls out from our proposed event-tokenization approach as follows. The non-agentive causation case in (31) is fleshed out by the agent's action as well as the theme's CoS tokens. (30B) is felt to be true because the progressive aspect may refer to the agent's action token alone contained within the entire causing event denoted by the VP. This partial modification option is not available in the non-agentive causation case in (30B), however, because the only possible target of modification by the progressive aspect is the theme's CoS. Accordingly, the sentence is felt to be false unless the sandcastle has undergone some $\mathrm{CoS}$ as a result of the causer's impact on it. Indeed, the example in (31B) becomes acceptable in the context in (32), which ensures that the sea has already crashed over the sandcastle.

(32) A: (Observing the sea crashing over a sandcastle): What is the sea doing?

B: $\quad$ It's destroying that sandcastle! (Non-agentive causation type) (Truswell 2011a:12)

Examples in $(33,34)$ show that the same pattern can be replicated in Indonesian with the causative accomplishment verb buka 'to open'.

(33) (Observing a strong wind approaching a fragile-looking front door of an old house)

Lihat! \#Angin sedang membuka pintu-itu!

Look wind PROG open door-that

'Look! The wind is opening that door.'

(34) A: (Observing B reaching his right hand into his pocket in front of the door of his house)

Ada apa?

exist what

'What is happening?' 


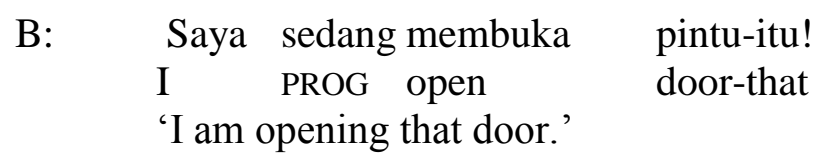

(33), an instance of the non-agentive causation type, is felt to be awkward by native Indonesian speakers because the causer subject angin 'wind' has not affected the theme in any way at the utterance time. However, (34), an instance of the agentive causation type, is fine even in the context where the speaker has not even touched the front door yet, but has just started his preparatory actions to put his intention to open the door, for example, by trying to find his house key in his pant's front pocket, or by extending his/her hands to the door knob to turn it.

5. Conclusion. In this paper, I have proposed to extend Martin's (2019) event-tokenization approach to causation to Indonesian causative accomplishment verbs. Our primary empirical focus has been the non-culminating, zero CoS construal of this verbal class and its origin. Martin's central hypothesis is that causation comes in two types depending on the agentivity of the external argument: the agentive causation type is understood in terms of two sub-event tokens: the agent's action and the theme's CoS whereas the non-agentive causation type is understood only in terms of the theme's CoS just as in anti-causative/inchoative constructions. I have demonstrated how this difference interacts with the maximality requirement of the partitive perfective operator $\mathrm{PFV}_{M}$ to yield the ACH effects in Indonesian, namely, the availability of the non-culminating, zero CoS construal with agent subjects, but not with causer subjects. I have also presented three independent pieces of evidence, internal to Indonesian, directly supporting the view that the agentive causation type is associated with the afore-mentioned two sub-event tokens whereas the non-agentive causation type is associated only with one of them.

The proposed analysis has two important implications, each worthy of further in-depth future investigations and verifications. Firstly, cross-linguistically speaking, the data reported here suggest that Indonesian behaves on a par with many other genetically unrelated languages, including Malagasy (Travis 2000, 2005), Tagalog (Dell 1983), Salish (Bar-el et al. 2005; Jacobs 2011, Kiyota 2008), Chinese (Tai 1984), Japanese (Ikegami 1980/1981, 1981, 1985; Kageyama 1996, 2002; Tsujimura 2003), Korean (Park 1993; Lee 2015), English (Oerhle 1976) and many other languages documented in Demirdache and Martin (2015) and Martin $(2015,2019)$, which are all reported to exhibit the non-culminating, zero $\mathrm{CoS}$ readings of causative verbs only when their subject is agentive. In other words, the results attained present new evidence from Indonesian for the $\mathrm{ACH}$ (Demirdache and Martin 2015), which establishes that the relevant construal is possible with causative accomplishment verbs when the subject is an agent, but not a causer. Secondly, as noted by other lexical semantic works including Tsujimura (2003) (see section 2 for some discussion on this point), it has been a perennial issue in the lexical semantics literature whether the notion of agentivity is linguistically represented. The results of this study show that the answer is resounding yes; agentivity has to be represented at some level of linguistic representation, either in the Lexical Conceptual Structure (Levin and Rappaport-Hovav 1995; Pustejovsky 1991) or in syntactic structures (Pylkkänen 2002; Harley 2009, 2013), because it has clear repercussions on the result entailment/culmination of causative accomplishment verbs.

\section{References}

Altschuler, Daniel. 2014. A typology of partitive aspectual operators. Natural Language \& Linguistic Theory 32(3). 735-775. https://doi.org/10.1007/s11049-014-9232-1. 
Altschuler, Daniel. 2016. Events, states and times: An essay on narrative discourse in English. Warsaw/Berlin: De Gruyter.

Bar-El, Leora, Henry Davis \& Lisa Matthewson. 2005. On non-culminating accomplishments. Proceedings of the 35th Annual Meeting of the North East Linguistic Society (NELS 35), 87102. Amherst, MA: GLSA, University of Massachusetts, Amherst.

Bonomi, Andrea. 1997. The progressive and the structure of events. Journal of Semantics 14(2).173-205. https://doi.org/10.1093/jos/14.2.173.

Dell, François. 1983. An aspectual distinction in Tagalog. Oceanic Linguistics 22/23(1/2).175-206.

Demirdache, Hamida \& Fabienne Martin. 2015. Agent control over non-culminating events. In Elisa Barrajón López, José Luis Cifuentes Honrubia \& Susana Rodrígues Rosique (eds.), Verb classes and aspect.185-217. Amsterdam/Philadelphia: John Benjamins.

Harley, Heidi. 2009. The morphology of nominalizations and the syntax of $v \mathrm{P}$. In Anastasia Ginnakidou \& Monika Rathert (eds.), Quantification, definiteness and nominalization, 321-343. Oxford: Oxford University Press.

Harley, Heidi. 2013. External arguments and the mirror principle: On the distinctness of voice and v. Lingua 125.34-57. https://doi.org/10.1016/j.lingua.2012.09.010.

Ikegami, Yoshihiko. 1980-1981. 'Activity' - 'Accomplishment' - 'Achievement' - doosi imi koozoo no ruikei. The rising generation 1980.12-1981.3. Tokyo: Kenkyusha.

Ikegami, Yoshihiko. 1981. "Suru” to "naru” no gengogaku: Kotoba to bunka no taiporozii e no siron. Tokyo: Taisyuukan.

Ikegami, Yoshihiko. 1985. 'Activity' - 'accomplishment' - 'achievement' - A language that can't say 'I burned it but it didn't burn' and one that can. In Adam Makkai \& Alan Melby (eds.), Linguistics and philosophy: Festschrift for Rulon S. Wells, 265-304. Amsterdam: John Benjamins.

Jacobs, Peter. 2011. Control in skuwxwu7mesh. Vancouver, BC: University of British Columbia dissertation.

Kageyama, Taro. 1996. Doosi imiron: Gengo to ninti no setten. Tokyo: Kurosio Publishers.

Kageyama, Taro. 2002. Kezime no nai Nihongo. Tokyo: Iwanami Publishers.

Kiyota, Masaru. 2008. Situation aspect and viewpoint aspect: From Salish to Japanese. Vancouver, BC: University of British Columbia dissertation.

Koenig, Jean-Pierre \& Nuttannart Muansuwan. 2000. How to end without ever finishing: Thai semi-perfectivity. Journal of Semantics 17(2).147-182. https://doi.org/10.1093/jos/17.2.147.

Lee, Juwon. 2015. An intention-based account of accomplishments in Korean. Austin, TX: University of Texas at Austin dissertation.

Levin, Beth \& Malka Rappaport-Hovav. 1995. Unaccusativity: At the syntax-lexical semantics interface. Cambridge, MA: MIT Press.

Martin, Fabienne. 2015. Explaining the link between agentivity and non-culminating causation. In Sarah D'Antonio, Mary Moroney \& Carol Rose Little (eds.), Proceedings of the 25th Semantics and Linguistic Theory Conference (SALT) 25. 246-266. Washington, DC \& Ithaca, NY: Linguistic Society of America \& Cornell Linguistics Circle.

Martin, Fabienne. 2019. Aspectual differences between agentive vs. non-agentive uses of causative predicates. Ms., Humboldt-Universität zu Berlin.

Martin, Fabienne. Forthcoming. Non-culminating accomplishements. Language and Linguistics Compass. https://doi.org/10.1111/lnc3.12346. 
Martin, Fabienne \& Zsófia Gyarmathy. Forthcoming. A more fine-grained typology of perfective operators. In Christopher Piñón (ed.), Empirical issues in syntax and semantics, vol. 12. Paris: CSSP-CNRS.

Martin, Fabienne \& Florian Schäfer. 2015. Sublexical modality in defeasible causative verbs. In Ana Arregui, María Luisa Rivero \& Andrés Salanova (eds.), Modality across syntactic categories, 87-108. Oxford: Oxford University Press.

Martin, Fabienne, Hongyuan Sun, Hamida Demirdache, and Jinhong Liu. 2018. Monomorphemic verbs in mandarin Chinese: Lexical aspect, event structure and non-culminating construals. Ms., Université de Nantes and Humboldt-Universität zu Berlin.

Oehrle, Richard. 1976. The grammatical status of the English dative alternation. Cambridge, MA: Massachusetts Institute of Technology dissertation.

Park, Ki-Seong. 1993. Korean causatives in role and reference grammar. Buffalo, NY: University of New York at Buffalo MA thesis.

Pylkkänen, Liina. 2002. Introducing arguments. Cambridge, MA: Massachusetts Institute of Technology dissertation

Pustejovsky, James. 1991. The syntax of event structure. Cognition 41(1-3).47-81. https://doi.org/10.1016/0010-0277(91)90032-Y.

Schäfer, Florian. 2008. The syntax of (anti-) causatives: External arguments in change-of-state contexts. Amsterdam: John Benjamins.

Tai, James H.-Y. 1984. Verbs and times in Chinese: Vendler's four categories. In David Testen, Veena Mishra \& Joseph Drogo (eds.), Papers from the parasession on lexical semantics, 289-296. Chicago, IL: Chicago Linguistic Society.

Travis, Lisa. 2000. Event structure in syntax. In Carol Tenny \& James Pustejovsky (eds.), Events as grammatical objects: The converging perspectives of lexical semantics and syntax, 145185. Palo Alto, CA: CSLI.

Travis, Lisa. 2005. Agents and causes in Malagasy and Tagalog. In Nomi Erteschik-Shir \& Tova Rapoport (eds.), The syntax of aspect: Deriving thematic and aspectual interpretation, 174189. New York: Oxford University Press.

Truswell, Robert. 2011a. Agentivity, aspectual classes, and the progressive. Ms., Edinburgh University.

Truswell, Robert. 2011b. Events, phrases, and questions. Oxford: Oxford University Press. Tsujimura, Natsuko. 2003. Event cancellation and telicity. In William McClure (ed.), Japanese/Korean Linguistics 12, 388-399. Stanford, CA: CSLI Publications. 